\title{
EVALUATION OF SOME PRE- AND POST-EMERGENCE HERBICIDES FOR WEED CONTROL IN YACON
}

\author{
J.J.C. SCHEFFER ${ }^{1}$, J.A. DOUGLAS ${ }^{2}$ and C.M. TRIGGS ${ }^{3}$
}

\author{
${ }^{I}$ New Zealand Institute for Crop \& Food Research Limited, Pukekohe Research \\ Station, Cronin Road, R.D. 1, Pukekohe \\ ${ }^{2}$ New Zealand Institute for Crop \& Food Research Limited, Ruakura Research \\ Centre, Private Bag 3123, Hamilton \\ ${ }^{3}$ Department of Statistics, University of Auckland, Private Bag 92 019, Auckland \\ Corresponding author: schefferj@crop.cri.nz
}

\section{ABSTRACT}

Weed control was investigated in yacon (Smallanthus sonchifolius Asteraceae), a herbaceous perennial that produces edible tubers. Eight pre-emergence (alachlor, acetochlor, simazine, diuron, pendamethalin, dimethanamid, methabenzthiazuron and metribuzin), and two postemergence (linuron and methabenzthiazuron) herbicides were evaluated in field trials at Pukekohe. All pre-emergence herbicides except metribuzin were tolerated by yacon, but the best weed control was achieved with acetochlor, metribuzin and dimethanamid. Weeds in the untreated control caused a $62 \%$ reduction $(\mathrm{P}<0.05)$ in root weight relative to acetochlor, alachlor, metribuzin and dimethanamid. The post-emergence herbicides were both phytotoxic to yacon top growth, but the plants subsequently recovered and plant crown production at harvest was not reduced relative to the control $(\mathrm{P}>0.05)$.

Keywords: Smallanthus sonchifolius, root crop, herbicide, weed control.

\section{INTRODUCTION}

Yacon (Smallanthus sonchifolius syn. Polymnia sonchifolia - Asteraceae ), a robust, large-leaved, herbaceous, perennial species from the Andean region of South America, produces sweet, edible, tuberous roots (Grau \& Rea 1997). It was originally introduced into New Zealand as a new vegetable (Endt 1983), but after a brief period of interest amongst growers it has largely remained a garden curiosity. More recently, interest in growing yacon has been revitalised because the storage roots are a source of fructooligosaccharides, a nutraceutical tea can be made from the leaves and stems, and it can be grown as a vegetable for export.

The yacon plant growth cycle begins in the spring with new growth from the dormant crowns. Plants may grow $2 \mathrm{~m}$ tall in a season with flowering taking place in midautumn. The top growth is susceptible to frost, and plants in the New Zealand environment over-winter as dormant crowns once frosts have killed the top growth. Pieces of the dormant, woody, rhizomatous crown are planted in spring. The crown pieces contain many bulb-like buds (turiones) from which the top growth sprouts (Zardini 1991). Yacon can also be grown from stem cuttings or tissue-cultured plantlets. The storage roots have no capacity to regenerate and the seed is mostly non-viable (Grau \& Rea 1997).

Yacon is traditionally planted in furrows with weed control achieved by moulding and inter-row cultivation (Grau \& Rea 1997). In trials at Pukekohe Research Station glyphosate has been used just prior to crop emergence to create a stale seed-bed, with further weed control carried out manually until canopy closure.

A range of chemicals have been found to be effective for weed control in species related to yacon. In coneflower (Echinacea purpurea), good tolerance was found to pendimethalin, oryzalin and a combination of oryzalin and chlorpropham applied at 
planting, and to terbacil, diuron and chlorpropham after plant establishment (Hartley 1993). In sunflower, linuron, metobromuron, alachlor, pendimethalin and prometryn applied shortly after sowing did not have phytotoxic effects (Salera 1992). The phytotoxicity of dimethanamid and acetochlor was low in sunflower when applied preplanting and lightly soil-incorporated (Popescu 1995). Metolachlor and propachlor applied before transplanting were damaging to lettuce, and pendimethalin severely stunted lettuce when applied after transplanting (Henderson \& Webber 1993). In dandelion, pre-emergence trifluralin (also incorporated), aziprotryne, chloroxuron and methabenzthiazuron were well tolerated in a direct seeded crop, but pendimethalin reduced plant numbers (Mitchell \& Abernethy 1994).

This paper reports on two field trials where candidate herbicides were evaluated for pre- or post emergence use in yacon crops.

\section{Pre-emergence trial}

\section{MATERIALS AND METHODS}

Dormant crown-pieces of yacon (line Ohaupo) were planted at $40 \mathrm{~cm}$ spacings on 2 November 2000 into open moulds $75 \mathrm{~cm}$ apart on a Mauku silt loam. The trial used a randomised block design with four replicates. Individual plots were made up of 40 plants in four rows with the outside rows and the two end plants of the middle rows acting as guard plants. This left 12 datum plants. The herbicide treatments (Table 1) were applied before crop emergence on 15 November 2000, using a modified Oxford sprayer, at a volume of 400 litres/ha at $200 \mathrm{kPa}$. The untreated control plots were not weeded. From emergence, plants were inspected regularly for symptoms of herbicide damage. The average plant height and the mean number of stems was recorded on 5 January 2001. On 6 January 2001 weed cover was estimated by eye in each plot using the following scale: $1=>80 \%$ weed cover, $2=50-80 \%$ weed cover, $3=25-50 \%$ weed cover, $4=10$ $25 \%$ weed cover, $5=1 \%-10 \%$ weed cover and $6=<1 \%$ weed cover.

Weeds were identified and counted on 7 January 2001 from three 200 x 200, 300 x 300 or $450 \times 450 \mathrm{~cm}$ quadrats in each plot. The smaller sized quadrats were used in treatments with large weed numbers. Plant heights, stem numbers and the fresh and dry weights of the yacon herbage were recorded on 16 March 2001 . Stems were cut about $15 \mathrm{~cm}$ above the ground. The crop was harvested between 10 and 27 July 2001. After washing, the number of roots, the fresh and dry weight of the roots, and the fresh weight of the plant crowns were recorded.

\section{Post-emergence trial}

For the post-emergence trial dormant crown-pieces of yacon line 42 (ex Lincoln) were planted on 7 December 2000 into open moulds in a Mauku silt loam. The moulds were $75 \mathrm{~cm}$ apart with plants spaced $30 \mathrm{~cm}$ in the rows. Plots were $4 \mathrm{~m}$ long with 4 rows. The outside rows and the two end plants in the middle rows were treated as guards. The plot recording area was $6 \mathrm{~m}^{2}$ with 20 plants. The trial was sprayed prior to crop emergence with acetochlor at $2.5 \mathrm{~kg} / \mathrm{ha}$ on 8 December 2000 and glyphosate at $1.5 \mathrm{~kg} / \mathrm{ha}$ on 13 December 2000. Post-emergence treatments (Table 4) were applied with the Oxford sprayer on 19 February 2001 when the plants were about $50 \mathrm{~cm}$ high and $30 \mathrm{~cm}$ wide. At this stage the treatment plots were weed free. The trial design was a randomised block with 3 replicates. Stem heights were measured on 22 April 2001 and stems were cut at $15 \mathrm{~cm}$ above the ground. Fresh and dry weight of leaves and stems were recorded. The plants were hand-dug between 31 July and 3 August and the number of roots, the fresh and dry weight of the roots as well as the fresh weight of the crowns were recorded. Data analysis

Data were analysed by analysis of variance using the GENSTAT package. To stabilise variance, counts were transformed to the log scale and percentages to the logit scale before analysis. Fitted means on the transformed scale were back transformed to the measurement scale of counts and percentages to display results. 


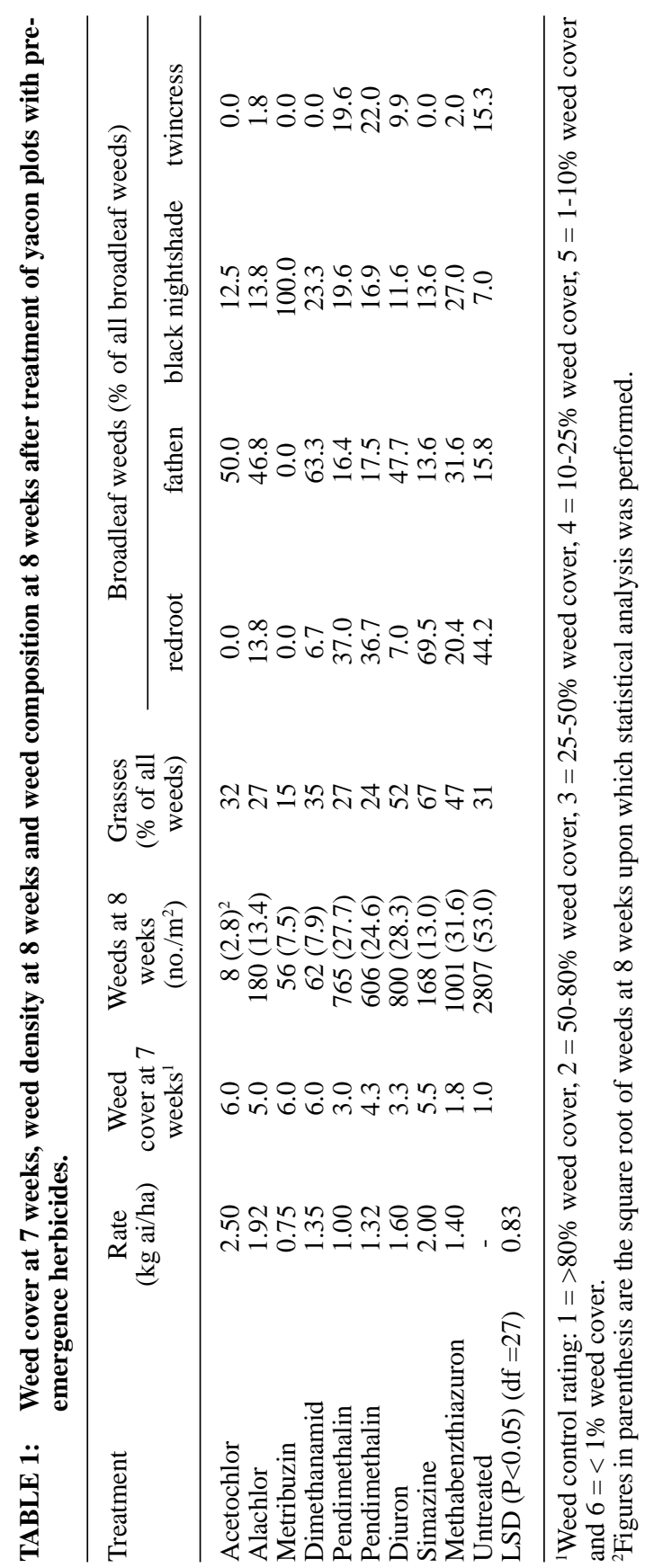




\section{Pre-emergence trial}

\section{RESULTS}

Plant emergence commenced 3 weeks after planting and a week after herbicide application, with none of the treatments delaying plant emergence. Yacon plants grew rapidly and after 6 weeks the average height was $25 \mathrm{~cm}$ with 4.5 stems per plant. Relative to the untreated control, none of the herbicide treatments delayed plant emergence. Only metribuzin showed symptoms of phytotoxicity with some leaf chlorosis and necrosis in all plots. However, there were no differences $(\mathrm{P}>0.05)$ between treatments in plant height and number of stems 6 weeks after treatment.

The main weeds in the trial site were annual grasses, including smooth witchgrass (Panicum dichotomiflorum), summer grass (Digitaria sanguinalis) and bristle grass (Setaria glauca), and the broadleaf weeds redroot (Amaranthus retroflexus), fathen

(Chenopodium album), black nightshade (Solanum nigrum) and twincress (Coronopus didymus) (Table 1).

Best weed control was achieved with acetochlor, metribuzin and dimethanamid. Seven weeks after application these treatments had $<1 \%$ weed cover and low weed numbers (Table 1), and provided significantly $(\mathrm{P}<0.05)$ better weed control than the other herbicide treatments apart from simazine. Weed cover in simazine was not significantly $(\mathrm{P}<0.05)$ different to the above three treatments, but weed numbers were higher $(\mathrm{P}<0.05)$ than in acetochlor. Methabenzthiazuron gave poor results with 50-80\% weed cover after 7 weeks. Compared to the untreated control this was not significantly different, although weed numbers were less than half. Neither pendimethalin nor diuron gave satisfactory weed control although these treatments were superior $(\mathrm{P}<0.05)$ to methabenzthiazuron.

Failure of treatments to provide adequate weed control was manifest as a check in yacon canopy growth and reduced herbage yields (Table 2), but there was no effect $(\mathrm{P}>0.05)$ on stem number 18 weeks after treatment (data not shown). The average yacon canopy height of $142 \mathrm{~cm}$ in acetochlor, metribuzin and dimethanamid treated plots was $23 \%$ higher $(\mathrm{P}<0.001)$ than in methabenzthiazuron treated plots $(109 \mathrm{~cm})$ and $38 \%$ higher than in the untreated control $(89 \mathrm{~cm})$. Plants from plots treated with simazine produced the tallest plants $(151 \mathrm{~cm})$.

TABLE 2: Herbage growth of yacon 18 weeks after application of pre-emergence herbicides.

\begin{tabular}{lcccc}
\hline Treatment & $\begin{array}{c}\text { Rate }(\mathrm{kg} \\
\text { ai/ha })\end{array}$ & $\begin{array}{c}\text { Mean height } \\
(\mathrm{cm})\end{array}$ & $\begin{array}{c}\text { Fresh weight } \\
(\mathrm{t} / \mathrm{ha})\end{array}$ & $\begin{array}{c}\text { Dry weight } \\
(\%)\end{array}$ \\
\hline Acetochlor & 2.50 & 144 & 42 & $13.6(-1.85)^{1}$ \\
Alachlor & 1.92 & 134 & 40 & $13.6(-1.84)$ \\
Metribuzin & 0.75 & 140 & 46 & $16.1(-1.65)$ \\
Dimethanamid & 1.35 & 143 & 40 & $13.5(-1.86)$ \\
Pendimethalin & 1.00 & 123 & 33 & $14.5(-1.79)$ \\
Pendimethalin & 1.32 & 133 & 39 & $13.7(-1.84)$ \\
Diuron & 1.60 & 124 & 30 & $14.6(-1.76)$ \\
Simazine & 2.00 & 151 & 46 & $13.0(-1.90)$ \\
Methabenzthiazuron & 1.40 & 109 & 25 & $15.7(-1.68)$ \\
Untreated & - & 89 & 13 & $19.5(-1.42)$ \\
LSD (P<0.05) (df =27) & & 19 & 7.7 & \\
\end{tabular}

${ }^{2}$ Figures in parenthesis are the transformed values for dry weight (\%) upon which statistical analysis was performed.

The herbage yield in the untreated control $(13 \mathrm{t} / \mathrm{ha})$ was $69 \%$ lower $(\mathrm{P}<0.001)$ than the average herbage yield in acetochlor, metribuzin and dimethanamid ( $42.6 \mathrm{t} / \mathrm{ha})$, whilst 
that in methabenzthiazuron (25 t/ha) was $41 \%$ lower. Relatively low herbage yields were also recorded in diuron (30 t/ha) and the low rate of pendimethalon (33 t/ha). The dry matter content of the yacon herbage in the untreated control was $19.5 \%$ compared to the average of $14.2 \%$ in the herbicide treatments $(\mathrm{P}<0.05)$.

Reductions in canopy height and herbage yield were associated with decreases in root $(\mathrm{P}<0.001)$ and crown yields $(\mathrm{P}<0.001)$, but numbers of roots produced were less affected $(\mathrm{P}<0.01)$ (Table 3).

TABLE 3: Washed root and crown yields of yacon 36 weeks after application of pre-emergence herbicides.

\begin{tabular}{lcccc}
\hline & & \multicolumn{2}{c}{ Roots } & Crowns \\
\cline { 3 - 4 } Treatment & $\begin{array}{c}\text { Rate } \\
\text { (kg ai/ha) }\end{array}$ & $\begin{array}{c}\text { Root number } \\
(1000 / \mathrm{ha})\end{array}$ & $\begin{array}{c}\text { Fresh wt } \\
(\mathrm{t} / \mathrm{ha})\end{array}$ & $\begin{array}{c}\text { Fresh wt } \\
\text { (t/ha) }\end{array}$ \\
\hline Acetochlor & 2.50 & $258(5.6)^{1}$ & 31 & 26 \\
Alachlor & 1.92 & $270(5.6)$ & 28 & 24 \\
Metribuzin & 0.75 & $294(5.7)$ & 27 & 26 \\
Dimethanamid & 1.35 & $246(5.5)$ & 26 & 28 \\
Pendimethalin & 1.00 & $266(5.6)$ & 22 & 24 \\
Pendimethalin & 1.32 & $236(5.5)$ & 24 & 26 \\
Diuron & 1.60 & $231(5.4)$ & 21 & 25 \\
Simazine & 2.00 & $218(5.4)$ & 21 & 19 \\
Methabenzthiazuron & 1.40 & $220(5.4)$ & 17 & 15 \\
Untreated & - & $185(5.2)$ & 11 & 4.0 \\
LSD (P<0.05) (df $=27)$ & & $(0.21)$ & 6.4 & \\
\hline
\end{tabular}

${ }^{1}$ Figures in parenthesis are the log of root number upon which statistical analysis was performed.

Highest root yields were produced in acetochlor (31 t/ha), alachlor (28t/ha), metribuzin $(27 \mathrm{t} / \mathrm{ha})$ and dimethanamid treated plots (26 t/ha) (Table 3$)$. This yield compares with $17 \mathrm{t} / \mathrm{ha}$ and $11 \mathrm{t} /$ ha respectively in the methabenzthiazuron treatment and the untreated control plots. The mean dry matter content of the roots was $11 \%$ and there were no significant differences between treatments $(\mathrm{P}>0.05)$. Crown yields were similar to the root yields and followed similar trends.

Post-emergence trial

Linuron and methabenzthiazuron were both phytotoxic to yacon when applied postemergence. Both chemicals caused severe leaf necrosis and leaf loss and significantly checked canopy growth in terms of height $(\mathrm{P}<0.05)$ and herbage yield $(\mathrm{P}<0.05)$ (Table $4)$. Fresh weight of yacon crowns was not affected by post-emergence herbicides $(\mathrm{P}>0.05)$.

TABLE 4: Yacon canopy height as well as herbage and crown yields after postemergence herbicide treatments.

\begin{tabular}{lcccc}
\hline Herbicide & $\begin{array}{c}\text { Rate } \\
(\mathrm{kg} \mathrm{ai} / \mathrm{ha})\end{array}$ & $\begin{array}{c}\text { Mean height } \\
(\mathrm{cm})\end{array}$ & $\begin{array}{c}\text { Herbage fresh } \\
\text { weight }(\mathrm{t} / \mathrm{ha})\end{array}$ & $\begin{array}{c}\text { Crown fresh } \\
\text { weight (t/ha) }\end{array}$ \\
\hline Linuron & 1.0 & 130 & 19.4 & 12.5 \\
Methabenzthiazuron & 1.4 & 140 & 21.4 & 12.9 \\
Untreated & - & 162 & 26.0 & 12.9 \\
LSD $(\mathrm{P}<0.05)(\mathrm{df}=4)$ & & 17 & 3.3 & 3.67 \\
\hline
\end{tabular}


The dry matter contents of stems and leaves did not differ significantly between treatments $(\mathrm{P}>0.05)$, averaging $11.2 \%$ and $16.5 \%$ in all three treatments. The average fresh root yield in linuron and methabenzthiazuron of $4 \mathrm{t} / \mathrm{ha}$ was $14 \%$ lower than the untreated control ( $4.8 \mathrm{t} / \mathrm{ha})$, but the difference was not significant $(\mathrm{P}>0.05)$. The average dry matter content of the roots in the three treatments was $9.1 \%$ and there were no treatment differences $(\mathrm{P}>0.05)$. There were no differences between treatments in crown yield (Table 4).

\section{DISCUSSION}

Several residual herbicides can be used successfully for pre-emergence weed control in yacon. Of the herbicides tested, acetochlor and dimethanamid are considered the most useful in terms of both weed control and crop safety. Metribuzin gave excellent weed control, but caused early crop damage. On a different soil type and different conditions this herbicide may cause more severe damage. However, the crown-pieces appeared to be very robust planting material and capable of surviving some early herbicide damage. Although simazine gave similar weed control to alachlor, simazine-treated yacon crops performed inconsistently, producing an excellent canopy and herbage yield, but having the third lowest fresh root yield. Although fresh root yield under simazine treatments were lower than under alachlor treatments, crown yield was higher in simazine than alachlor treatments. Pendimethalin and diuron provided less effective weed control than the other herbicides, and methabezthiazuron cannot be considered a good option because of its poor weed control.

Neither linuron nor methabenzthiazuron applied post-emergence were well tolerated by yacon but after the initial setback the plants grew well. The later planting of the post-emergence trial and the defoliation of the plants in February/March had a major effect on the development of the tuberous roots compared to the pre-emergence herbicide trial. The post-emergence treatments had no significant effect on the storage root yield but the low level of root production recorded means that this result needs to be treated with caution. Nevertheless at harvest the plant-crowns from the herbicide treated plots were not significantly different from the untreated controls, indicating that the plants were not permanently damaged and that post- emergence herbicide application could be used to salvage a yacon crop where pre-emergence herbicides were not very effective. A refinement of this would be to use directed or shielded postemergent herbicide applications. Glufosinate-ammonium and alachlor were successfully used in this manner in a commercial yacon planting at Pukekohe this season with little obvious damage (J. Scheffer, unpubl. data).

A sound weed control programme for yacon establishment requires early land preparation and the application of the "stale seedbed" technique. This technique allows weeds to germinate; they are then eliminated with a contact herbicide such as glyphosate, in conjunction with a pre-emergence treatment. In warm conditions, adequate soil fertility and good soil moisture yacon grows very quickly and will develop a dense canopy within two months. If a crop establishment programme is well planned there should be little need for post-emergence treatments.

\section{REFERENCES}

Endt, A. 1983: The yacon and aniu new from South America. Commercial Hort. July: $14-15,32$.

Grau, A.; Rea, J. 1997: Yacon Smallanthus sonchifolius (Poepp. \& Endl.) H. Robinson. In: Hermann, M; Heller, J. ed. Andean roots and tubers: Ahipa, arracacha, maca, yacon. International Plant Genetic Resources Institute, Rome. Pp. 202-242.

Hartley, M.J. 1993: Herbicide tolerance of and weed control in three medicinal herbs. Proc. 46th N.Z. Weed and Pest Control Conf:: 30-34.

Henderson, C.W.L.; Webber, M.J. 1993: Phytotoxicity to transplanted lettuce (Lactuca sativa) of three pre-emergence herbicides - metolachlor, pendimethalin and propachlor. Aust. J. Exp. Agric. 33: 373-380. 
Mitchell, R.B.; Abernethy, R.J. 1994: Tolerance of medicinal plants to soil active herbicides. Proc. 47th N.Z. Plant Prot. Conf: 183-187.

Propescu, A. 1995: New herbicide treatments for controlling the annual weeds in sunflower crops. Romanian Agricultural Research No 4: 89-92.

Salera, E. 1992: Sunflowers: evaluation of the selectivity of some herbicide compounds applied pre-emergence at different times. Informatore Agrario. 48: 11, 135-138.

Zardini, E. 1991: Ethnobotanical notes on Yacon. Econ. Bot. 45: 72-85.

\section{APPENDIX: Herbicides and their formulations used in this study}

acetochlor (Roustabout, ec), alachlor (Lasso, ec), dimethanamid (Frontier, ec), diuron (Karmex, df), linuron (Linuron, df), methabenzthiazuron (Tribunil, wp), pendimethalin (Stomp, ec), simazine (Gesatop, sc).

( $\mathrm{ec}=$ emulsifiable concentrate; $\mathrm{df}=$ dry flowable; $\mathrm{wp}=$ wettable powder; $\mathrm{sc}=$ suspension concentrate). 